\title{
Long-term use of darunavir/ritonavir- containing regimens in daily practice in Belgium: retrospective observational cohort data of 1701 HIV-patients
}

Stéphane De Wit, Eric Florence, Linos Vandekerckhove, Bernard Vandercam, Jean-Christophe Goffard, Eric Van Wijngaerden, Michel Moutschen, Remy Demeester, Pushpike Thilakarathne, Hilde Piryns \& for the BREACH* Consortium

To cite this article: Stéphane De Wit, Eric Florence, Linos Vandekerckhove, Bernard Vandercam, Jean-Christophe Goffard, Eric Van Wijngaerden, Michel Moutschen, Remy Demeester, Pushpike Thilakarathne, Hilde Piryns \& for the BREACH* Consortium (2018): Long-term use of darunavir/ ritonavir-containing regimens in daily practice in Belgium: retrospective observational cohort data of 1701 HIV-patients, Acta Clinica Belgica, DOI: 10.1080/17843286.2018.1458428

To link to this article: https://doi.org/10.1080/17843286.2018.1458428

曲 Published online: 06 Apr 2018.

Џ Article views: 7
Submit your article to this journal $\widetilde{\pi}$ 


\title{
Long-term use of darunavir/ritonavir-containing regimens in daily practice in Belgium: retrospective observational cohort data of 1701 HIV-patients
}

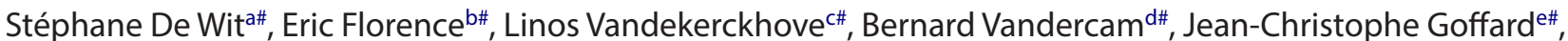 \\ Eric Van Wijngaerden ${ }^{f \#}$, Michel Moutschen ${ }^{\#}$, Remy Demeester $^{\mathrm{h} \#}$, Pushpike Thilakarathne ${ }^{\mathrm{i}}$, Hilde Piryns for the \\ BREACH* Consortium \\ aSaint-Pierre University Hospital, Université Libre de Bruxelles, Brussels, Belgium; 'bnstitute of Tropical Medicine, Antwerp, Belgium; \\ 'University Hospital Ghent, Ghent, Belgium; 'Saint-Luc University Hospital, Brussels, Belgium; eUniversity Hospital Erasme, Brussels, Belgium; \\ fUniversity Hospital Leuven, Leuven, Belgium; 'Liège University Hospital, Belgium; hUniversity Hospital Charleroi, Charleroi, Belgium; \\ 'Statistical Department, Janssen-Cilag NV, Beerse, Belgium; 'Medical Department, Janssen-Cilag NV, Beerse, Belgium
}

\begin{abstract}
Background: Once daily (QD) ritonavir or cobicistat-boosted darunavir (DRV/b), in combination with other antiretrovirals (ARVs), is recommended as a first-line option for human immunodeficiency virus-infected patients in European and USA guidelines. The objective of this study was to analyse the outcomes of DRV/r QD-based antiretroviral therapy (ART) regimens in real-life settings.

Methods: This is an observational, non-interventional, non-comparative, retrospective, multicentre cohort study. Data were collected from the databases of eight Belgian AIDS Reference Centres. All patients who received at least one dose of DRV/r QD, regardless of background ARV regimen, with a minimum follow-up of 6 months were included.

Results: Data from 1701 subjects were collected. Most were male (66.5\%) with a mean age of 42.9 years, $33.1 \%$ were treatment-naïve and $66.9 \%$ were ART experienced. During a median follow-up of 2.45 years ( $95 \% \mathrm{Cl}: 1.50-3.34)$, the probability to remain on treatment was $87 \%$ for the first year, $79 \%$ for the second year. DRV/r was well tolerated with few discontinuations due to adverse events (6.9\%) or virological failure $(0.8 \%)$. Among the 1138 treatment-experienced patients, 111 (9.8\%) patients received DRV/r QD monotherapy.

Conclusions: This retrospective cohort analysis confirms the long-term effectiveness and good tolerability of DRV/r QD in a real-life setting. No unexpected adverse events were reported.
\end{abstract}

\section{KEYWORDS}

Belgium; HAART (highly active antiretroviral therapy); HIV (human immunodeficiency virus); darunavir; once-daily

\section{Introduction}

Darunavir (DRV) is a human immunodeficiency virus-1 (HIV-1) protease inhibitor (PI) approved for the treatment of HIV-1 positive subjects [1]. DRV is co-administered with low-dose ritonavir (DRV/r) or cobicistat (DRV/c) as pharmacokinetic boosters. Boosted DRV, in combination with other antiretrovirals (ARVs), is recommended as a first-line option for HIV-positive patients in current guidelines [2,3].

$\mathrm{DRV} / \mathrm{r} 800 \mathrm{mg} / 100 \mathrm{mg}$ once daily (QD) showed sustained efficacy and was well tolerated in treatment-naïve patients in clinical trials (192-week ARTEMIS study [4], 96-week FLAMINGO study [5] and 96-week ARDENT study [6]) as well as in treatment-experienced patients with no DRV resistance-associated mutations (ODIN study [7]). DRV/r has a high genetic barrier to resistance, as shown in a diverse population of patients treated with a DRV $800 \mathrm{mg}$ QD-based regimen and in clinical practice in the United Kingdom $[8,9]$.
Several observational studies reflecting routine clinical practice in different countries have demonstrated the effectiveness and tolerability profile of DRV/r-containing regimens [10-13].

Some observational retrospective studies report the use of DRV/r monotherapy as treatment simplification strategy, which is however not approved by the European Medicines Agency and only recommended in some guidelines for a selected group of patients $[2,14,15]$.

$\mathrm{DRV} / \mathrm{r} 800 \mathrm{mg} / 100 \mathrm{mg}$ QD is available and reimbursed in Belgium since 2010, but long-term data in real-life clinical settings are limited. The objective of this retrospective study was to analyse the use of DRV/r $800 \mathrm{mg} / 100 \mathrm{mg}$ QD-based antiretroviral therapy (ART) regimens in real-life settings in Belgium. This is also relevant as in the meantime two new formulations with darunavir have become available in Belgium, a fixed-dose-combination with the pharmacological booster cobicistat (DRV/c, since 1/12/2015) [16] and a 
single-tablet regimen (since 1/4/2018) with DRV/c and the two NRTIs tenofovir-alafenamide (TAF) and emtricitabine (FTC) $[17,18]$, offering new more convenient opportunities to integrate DRV into the ART.

\section{Materials and methods}

This is an observational, non-interventional, non-comparative, retrospective, multicentre cohort study. Data were collected from 1 January 2010 to the end of 2014 in eight AIDS Reference Centres. The ethics committee of each centre approved the study. Patients were included if they were $\geq 18$ years of age with a confirmed HIV-1 infection, treatment-naïve or experienced, had received at least one dose of DRV/r $800 \mathrm{mg} / 100 \mathrm{mg}$ QD with at least six months follow-up of their HIV-1 RNA and CD4 cell count after DRV/r initiation. DRV was administered as $2 \times 400 \mathrm{mg}$ QD or $1 \times 800 \mathrm{mg}$ QD. Patients participating in ongoing clinical trials were excluded.

Baseline (BL) was defined as the start of DRV/r treatment. Data collected were BL information at DRV/r initiation, follow-up measurements (after six months and after one, two, three and four years of treatment or at the last available measure point or until DRV/r was discontinued) and reasons for discontinuation. The primary endpoints were time to, rate of and reason for discontinuation of $\mathrm{DRV} / \mathrm{r}$ treatment, as a simple measure of real-world effectiveness. Discontinuation was defined as treatment interruption for a period of at least 90 days and classified according the D:A:D classification [19]. Routine laboratory tests (total cholesterol, HDL cholesterol, LDL cholesterol, triglycerides, serum creatinine and eGFR, with sites using the Cockcroft-Gault or the MDRD formula) were documented. An analysis of previous medical and treatment history was outside the scope of this study.

Statistical analyses were performed on all patients who initiated DRV $800 \mathrm{mg}$ QD during the study period. Demographic and primary analyses were done on the overall population using Kaplan-Meier survival analysis and log-rank tests to assess outcomes. Analyses on laboratory data were limited to subjects with an observed BL (last available value within the six months prior to DRV $800 \mathrm{mg}$ QD initiation) and at least one post-BL value.

All statistical analyses were performed with the SAS program (Statistical Analysis System, Version 9.3).

\section{Results}

\section{Baseline characteristics}

Data from 1701 HIV-positive patients were collected. Most were male (66.5\%), of Caucasian (48.6\%) or of African (29.6\%) ethnicity, and the mean age was 42.9 years. Mode of HIV acquisition was heterosexual in
$42.2 \%$ or men who have sex with men (MSM) in $41.6 \%$ of patients. One-third (33.1\%) were treatment-naïve (of which $44.2 \%$ had a baseline HIV-1 RNA $\geq 100,000$ copies $/ \mathrm{mL}$ ) and $66.9 \%$ were ART-experienced (of which $48.5 \%$ were virologically suppressed with HIV-1 RNA $<50$ copies $/ \mathrm{mL}$ ). Among naïve patients, $56.5 \%$ initiated ART with CD4 $\leq 350$ cells $/ \mathrm{mm}^{3}$. Most patients (59.0\%) received a tenofovir disoproxil fumarate/emtricitabine (TDF/FTC) backbone, while $11.9 \%$ of patients did not receive a nucleoside reverse transcriptase inhibitor (NRTI) backbone regimen. DRV/r QD monotherapy was used in $6.8 \%$. Demographics and baseline characteristics are shown in Table 1.

\section{Primary endpoints}

\section{Probability to remain on treatment}

Time to discontinuation of DRV/r, defined as the time from first treatment initiation until the end of treatment, is shown in Figure 1 (Kaplan-Meier estimates). No significant differences were observed in the subgroup analyses between naïve patients with BL HIV-1 RNA above or below 100,000 copies $/ \mathrm{mL}$ ( $p=0.3129$ log-rank test) as well as between experienced patients with a $\mathrm{BL}$ HIV-1 RNA above or below 50 copies/mL ( $p=0.3895$ log-rank test). There were also no differences observed when stratified by gender, race, NRTI backbone or baseline CD4 count.

Overall, 1242 patients (73.0\%) remained on DRV/r QD treatment as part of their ART during a median follow-up of 2.45 years (Table 2). The probability to remain on $\mathrm{DRV} / \mathrm{r}$ QD treatment was $87.0 \%$ for the first year and $78.9 \%$ for the second year.

\section{Reasons for treatment discontinuation}

The main reasons for treatment discontinuation were treatment simplification (6.7\%), adverse events (6.9\%, $4.0 \%$ were GI tract related) and patients' or physicians' decision (3.5\%), with minor differences in treatment discontinuation rates between naïve and experienced patients (Table 3). Discontinuation due to virological failure was noted in 13 patients $(0.8 \%)$ and due to concern of cardiovascular disease and liver toxicity in 3 patients $(0.2 \%)$ each.

\section{Secondary endpoints}

\section{Probability to maintain virological suppression}

Most experienced and naïve patients which responded to treatment (HIV-1 RNA $<50$ copies/mL, $n=1504$ ) remained virologically suppressed. After 1, 2 and 3 years of follow-up 89,85 and $82 \%$ of the patients maintained virological suppression. The rate was slightly higher in the initially naïve population (94, 90 and $88 \%$ ) than in the treatment experienced (88, 83 and $80 \%)$. 
Table 1. Baseline characteristics.

\begin{tabular}{|c|c|c|c|}
\hline $\begin{array}{l}\text { Baseline charac- } \\
\text { teristics }\end{array}$ & $\begin{array}{l}\text { All } n=1701 \\
(100 \%)\end{array}$ & $\begin{array}{c}\text { All Naïve } n= \\
563(33 \%)\end{array}$ & $\begin{array}{l}\text { All Experi- } \\
\text { enced } n= \\
1138(67 \%)\end{array}$ \\
\hline $\begin{array}{l}\text { Mean age, years } \\
\text { (SD) }\end{array}$ & $42.9(11.1)$ & $39.8(10.6)$ & $44.5(11.0)$ \\
\hline \multicolumn{4}{|l|}{ Gender, $n(\%)$} \\
\hline Male & 1132 (66.5\%) & 424 (75.3\%) & 708 (62.2\%) \\
\hline Female & $569(33.5 \%)$ & $139(24.7 \%)$ & 430 (37.8\%) \\
\hline \multicolumn{4}{|l|}{ Ethnicity, $n$ (\%) } \\
\hline Caucasian & 826 (48.6\%) & 302 (53.6\%) & 524 (46.0\%) \\
\hline African & 503 (29.6\%) & 112 (19.9\%) & 391 (34.4\%) \\
\hline Other & $29(1.7 \%)$ & $10(1.8 \%)$ & $19(1.7 \%)$ \\
\hline Unknown & 343 (20.2\%) & 139 (24.7\%) & 204 (17.9\%) \\
\hline \multicolumn{4}{|l|}{$\begin{array}{l}\text { Mode of infec- } \\
\text { tion, } n(\%)\end{array}$} \\
\hline Heterosexual & 718 (42.2\%) & 185 (32.9\%) & $533(46.8 \%)$ \\
\hline $\begin{array}{l}\text { Homo/bisex- } \\
\text { ual }\end{array}$ & 707 (41.6\%) & $308(54.7 \%)$ & 399 (35.1\%) \\
\hline $\begin{array}{l}\text { Injecting drug } \\
\text { user }\end{array}$ & $35(2.1 \%)$ & $8(1.4 \%)$ & $27(2.4 \%)$ \\
\hline Perinatal & $16(0.9 \%)$ & $2(0.4 \%)$ & 14 (1.2\%) \\
\hline $\begin{array}{l}\text { Other/Un- } \\
\text { known }\end{array}$ & 225 (13.2\%) & $60(10.6 \%)$ & 165 (14.5\%) \\
\hline \multicolumn{4}{|l|}{$\begin{array}{l}\text { HIV-1 RNA, cop- } \\
\text { ies/mL, } n(\%)\end{array}$} \\
\hline$<50$ & 563 (33.1\%) & $11(2.0 \%)^{\mathrm{a}}$ & 552 (48.5\%) \\
\hline$\geq 50$ & 1039 (61.0\%) & 508 (90.2\%) & 531 (46.6\%) \\
\hline Unknown & 99 (5.8\%) & 44 (7.8\%) & 55 (4.8\%) \\
\hline $\begin{array}{l}\text { CD4 cells } / \mathrm{mm}^{3}, \\
\text { mean (SD) }\end{array}$ & $441.8(287.1)$ & $311.6(216.2)$ & $506.0(296.0)$ \\
\hline \multicolumn{4}{|l|}{$\begin{array}{l}\mathrm{CD} 4 \text { cells } / \mathrm{mm}^{3}, \\
n(\%)\end{array}$} \\
\hline$<50$ & $122(7.2 \%)$ & 71 (12.6\%) & 51 (4.5\%) \\
\hline$\geq 50$ and $<200$ & 214 (12.6\%) & 103 (18.3\%) & $111(9.8 \%)$ \\
\hline $\begin{array}{l}\geq 200 \text { and } \\
<350\end{array}$ & 314 (18.5\%) & $144(25.6 \%)$ & $170(14.9 \%)$ \\
\hline $\begin{array}{l}\geq 350 \text { and } \\
<500\end{array}$ & 370 (21.8\%) & $132(23.4 \%)$ & $238(20.9 \%)$ \\
\hline$\geq 500$ & 599 (35.2\%) & 85 (15.1\%) & 514 (45.2\%) \\
\hline Unknown & $82(4.8 \%)$ & $28(5.0 \%)$ & 54 (4.7\%) \\
\hline $\begin{array}{l}\text { CD4 nadir, mean } \\
\text { (SD) }\end{array}$ & $249.0(177.3)$ & $275.8(184.4)$ & $235.7(172.2)$ \\
\hline \multicolumn{4}{|l|}{$\begin{array}{l}\text { Current Back- } \\
\text { bone, } n(\%)\end{array}$} \\
\hline TDF/FTC & 1003 (59.0\%) & 409 (72.6\%) & 594 (52.2\%) \\
\hline $\mathrm{ABC} / 3 \mathrm{TC}$ & 259 (15.2\%) & 84 (14.9\%) & $175(15.4 \%)$ \\
\hline Other & 237 (13.9\%) & $19(3.4 \%)$ & 218 (19.2\%) \\
\hline $\begin{array}{l}\text { No NRTI } \\
\text { backbone }\end{array}$ & $202(11.9 \%)$ & $51(9.1 \%)$ & $151(13.3 \%)$ \\
\hline \multicolumn{4}{|l|}{$\begin{array}{l}\text { Combinations if } \\
\text { no NRTI back- } \\
\text { bone, } n(\%)\end{array}$} \\
\hline $\begin{array}{l}\mathrm{DRV} / \mathrm{r} \text { mono- } \\
\text { therapy }\end{array}$ & $116(6.8 \%)$ & $5(0.9 \%)$ & $111(9.8 \%)$ \\
\hline $\mathrm{DRV} / \mathrm{r}+\mathrm{RAL}$ & $47(2.8 \%)$ & $29(5.2 \%)$ & $18(1.6 \%)$ \\
\hline $\mathrm{DRV} / \mathrm{r}+\mathrm{DTG}$ & $12(0.7 \%)$ & $9(1.6 \%)$ & $3(0.3 \%)$ \\
\hline $\mathrm{DRV} / \mathrm{r}+\mathrm{NNRTI}$ & $8(0.5 \%)$ & $1(0.2 \%)$ & $7(0.6 \%)$ \\
\hline $\begin{array}{l}\mathrm{DRV} / \mathrm{r}+\mathrm{NNRTI} \\
+\mathrm{RAL}\end{array}$ & $9(0.5 \%)$ & $2(0.4 \%)$ & $7(0.6 \%)$ \\
\hline $\begin{array}{l}\text { Other combi- } \\
\text { nations }\end{array}$ & $10(0.6 \%)$ & $5(0.9 \%)$ & $5(0.4 \%)$ \\
\hline
\end{tabular}

aThe relatively high-rate of ART naïve subjects with a $\mathrm{VL}<50$ copies $/ \mathrm{mL}$ is unusual. In hindsight, some of these subjects might have been on ART before, however did not disclose this to their centre. As centres within Belgium have implemented collaborations in exchanging patients' charts, it is assumed that these subjects might have transferred from clinics outside of Belgium.

\section{Immunological response}

As expected, CD4 cell count at BL was higher in experienced vs. naïve patients ( 506 cells $/ \mathrm{mm}^{3}$ vs. 312 cells/ $\left.\mathrm{mm}^{3}\right)$. CD4 cell count increased by an average of 107 cells $/ \mathrm{mm}^{3}$ and 330 cells $/ \mathrm{mm}^{3}$ in experienced and naïve patients, respectively.
Lipids and renal parameters

Laboratory parameters, including lipids (triglycerides, cholesterol, HDL-C, LDL-C) and eGFR, remained stable throughout the observation period (Table 4).

\section{Analysis of outcome in subjects on DRV/r monotherapy}

The subgroup of 111/1138 experienced patients without previous DRV exposure (9.8\%), which initiated DRV/r monotherapy, was analysed. The most frequent reasons for discontinuation of last ART regimen prior to DRV monotherapy were classified as due to 'Toxicity, predominantly from kidneys' 30\% (33/111) and due to the 'Simplified treatment available' $23.4 \%$ (26/111). Compared to the overall group of ART experienced patients, patients on $\mathrm{DRV} / \mathrm{r}$ monotherapy were older (mean age 49.5 years vs. 44.5 years), predominantly of Caucasian ethnicity $(65.8 \%$ vs. $46.0 \%)$ and virologically suppressed at baseline $(84.7 \%$ vs. $48.5 \%)$. There was no difference in gender and CD4 nadir (mean 223 cells $/ \mathrm{mm}^{3}$ in monotherapy patients vs. 235 cells $/ \mathrm{mm}^{3}$ in other experienced patients).

In the DRV/r QD monotherapy group, 28 of 111 patients $(25.2 \%)$ discontinued treatment during a median follow-up of 2.55 years and the probability to remain on treatment was $81.3 \%$ for both the first and second years. Whether these subjects discontinued $\mathrm{DRV} / \mathrm{r}$ or intensified their monotherapy regimen with additional ARVs is not known. The probability to remain on DRV/r in the monotherapy subgroup did not differ significantly from the overall cohort on DRV/r QDcontaining combination regimen $(73.0 \%, p=0.4496 \mathrm{log}$ rank test). Mean CD4 nadir in patients (28/111) who discontinued monotherapy was 208 and $228 \mathrm{cells} / \mathrm{mm}^{3}$ for those subjects $(83 / 111)$ that were still on treatment $(p=0.0781, t$-test). A low CD4 nadir $(<100$ or $<200$ cells $/ \mathrm{mm}^{3}$ ) was not associated with treatment failure. The main reasons for treatment discontinuations in the group receiving monotherapy were adverse events (mainly GI tract disturbances).

\section{Discussion}

This retrospective cohort analysis describes the longterm outcomes with once-daily DRV/r-containing regimens in a diverse patient population in Belgium. The $\mathrm{DRV} / \mathrm{r}$ QD-based regimens had a durable virological efficacy and a good tolerability with no major differences between treatment-naïve and -experienced patients.

Compared to previous DRV/r trials, some differences regarding baseline characteristics are noteworthy: while previous studies predominantly included Caucasian patients (e.g. 80\% in PROTEA [20] and $\sim 90 \%$ in MONET [21]), they only represent half of the patients (48.6\%) in this cohort. Similar to the Swedish InfCare study [22], about one-third of the patients were of African ethnicity. More recently published clinical 
A) Naïve patients

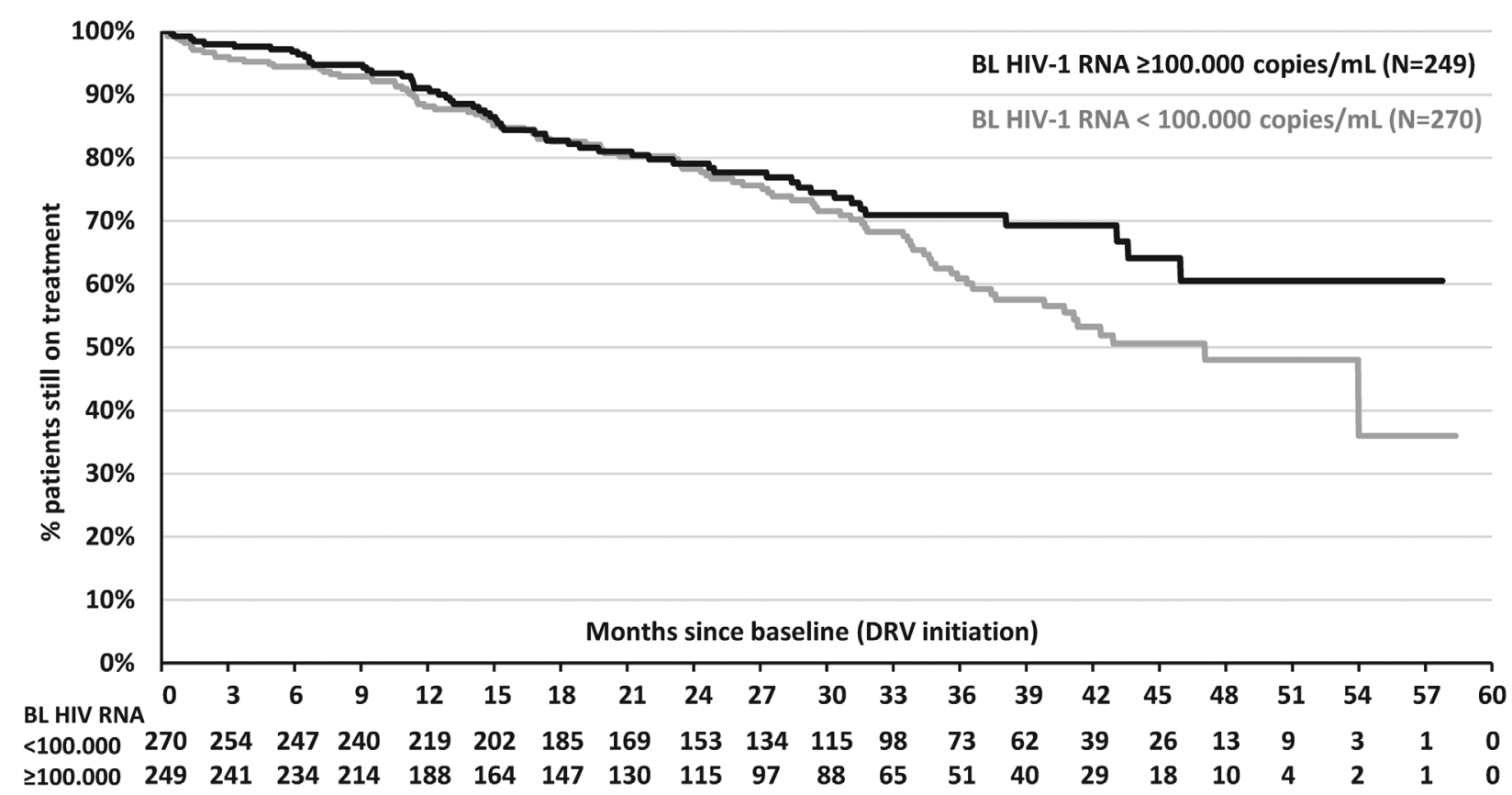

B)

Experienced patients

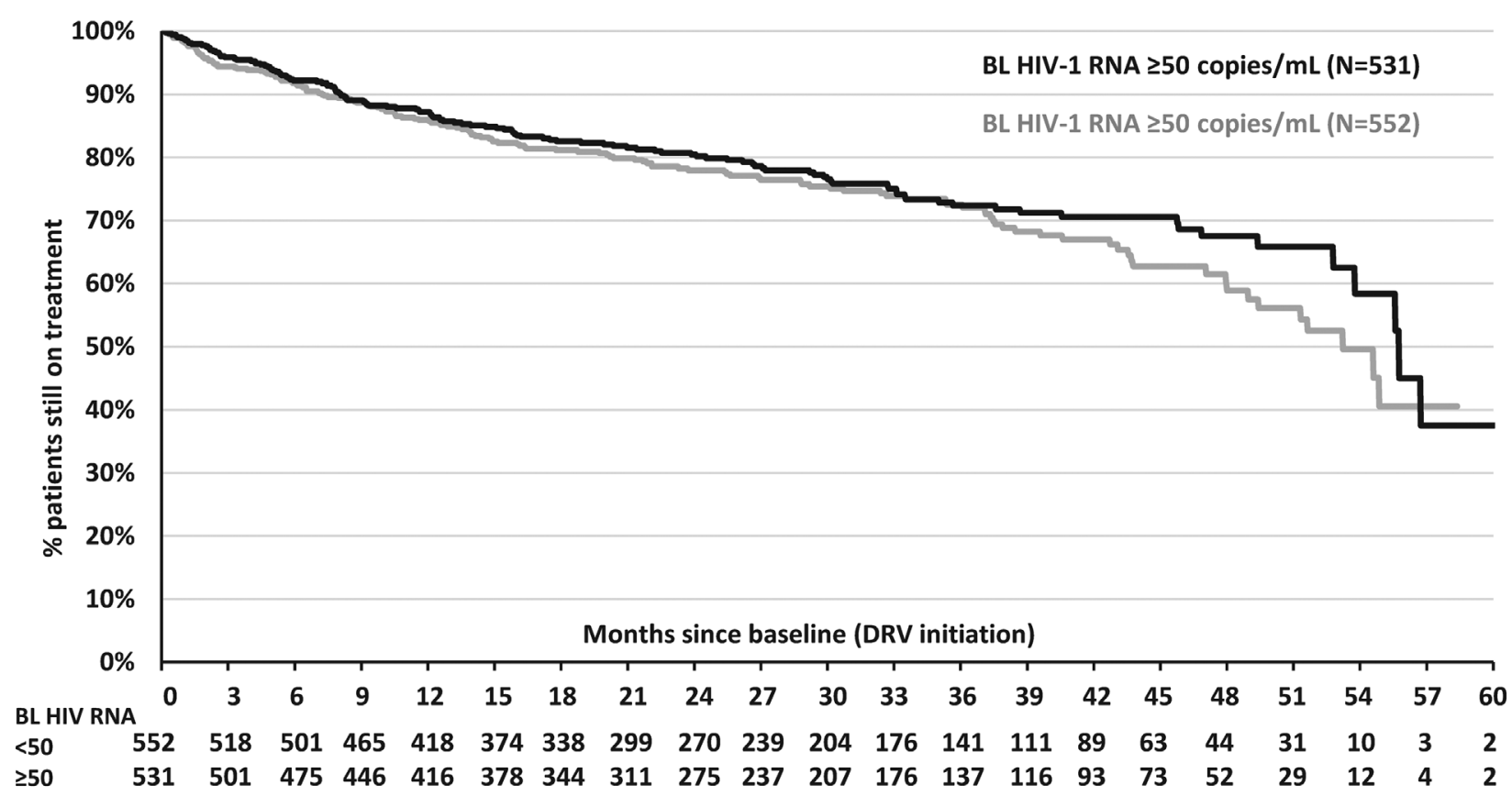

Figure 1. Time to treatment discontinuation (Kaplan-Meier estimates) for (A) all naïve patients (stratified by BL HIV-1 RNA $<100,000$ copies $/ \mathrm{mL}$ and $\geq 100,000$ copies $/ \mathrm{mL}$ ) and (B) all experienced patients (stratified by BL HIV- 1 RNA $<50$ copies $/ \mathrm{mL}$ and $\geq 50$ copies $/ \mathrm{mL}$ ) on a DRV/r QD-containing regimen.

Table 2. Probability to remain on DRV/r QD treatment.

\begin{tabular}{|c|c|c|c|c|}
\hline & & All $n=1701$ (100\%) & All Naïve $n=563$ (33\%) & $\begin{array}{c}\text { All Experienced } n=1138 \\
(67 \%)\end{array}$ \\
\hline \multirow[t]{2}{*}{ Treatment status, $n(\%)$} & $\begin{array}{l}\text { Remained on DRV/r QD } \\
\text { treatment }\end{array}$ & $1242(73.0 \%)$ & $402(71.4 \%)$ & $840(73.8 \%)$ \\
\hline & Discontinued & $459(27.0 \%)$ & $161(28.6 \%)$ & $298(26.2 \%)$ \\
\hline Median follow-up, years (95\% Cl) & & $2.45(1.50-3.34)$ & $2.42(1.45-3.29)$ & $2.46(1.52-3.36)$ \\
\hline Probability to remain on $\mathrm{DRV} / \mathrm{r}$ & 1st year & $87.0 \%(85.2-88.5 \%)$ & $89.0 \%(86.0-91.4 \%)$ & $85.9 \%(83.8-87.9 \%)$ \\
\hline \multirow{2}{*}{ QD treatment $(95 \% \mathrm{Cl})$} & 2nd year & $78.9 \%(76.7-80.9 \%)$ & $78.2 \%(74.2-81.7 \%)$ & $79.2 \%(76.6-81.6 \%)$ \\
\hline & $3 r d$ year & $69.1 \%(66.3-71.7 \%)$ & $64.5 \%(59.2-69.2 \%)$ & $71.4 \%$ (68.1-74.4\%) \\
\hline
\end{tabular}


Table 3. Reasons for treatment discontinuation.

\begin{tabular}{|c|c|c|c|}
\hline & $\begin{array}{c}\text { All } n=1701 \\
(100 \%)\end{array}$ & $\begin{array}{c}\text { All Naïve } n= \\
563(33 \%)\end{array}$ & $\begin{array}{c}\text { All Experi- } \\
\text { enced } n= \\
1138(67 \%)\end{array}$ \\
\hline $\begin{array}{l}\text { Discontinuation, } \\
n(\%)\end{array}$ & $459(27.0 \%)$ & $161(28.6 \%)$ & $298(26.2 \%)$ \\
\hline $\begin{array}{l}\text { Virological } \\
\quad \text { failure, } n(\%)\end{array}$ & $13(0.8 \%)$ & $7(1.2 \%)$ & $6(0.5 \%)$ \\
\hline $\begin{array}{l}\text { Adverse events, } \\
n(\%)\end{array}$ & 119 (6.9\%) & $34(6.1 \%)$ & $85(7.4 \%)$ \\
\hline $\begin{array}{l}\text { Hypersensitiv- } \\
\text { ity reaction }\end{array}$ & $10(0.6 \%)$ & $1(0.2 \%)$ & $9(0.8 \%)$ \\
\hline $\begin{array}{l}\text { Abnormal fat } \\
\text { redistribution }\end{array}$ & $7(0.4 \%)$ & $1(0.2 \%)$ & $6(0.5 \%)$ \\
\hline $\begin{array}{l}\text { Toxicity - Gl } \\
\text { Tract }\end{array}$ & $69(4.0 \%)$ & $23(4.1 \%)$ & $46(4.0 \%)$ \\
\hline Toxicity - CNS & $5(0.3 \%)$ & $1(0.2 \%)$ & $4(0.4 \%)$ \\
\hline $\begin{array}{l}\text { Concern of } \\
\text { cardiovascular } \\
\text { disease }\end{array}$ & $3(0.2 \%)$ & $1(0.2 \%)$ & $2(0.2 \%)$ \\
\hline Other & $25(1.4 \%)$ & $7(1.2 \%)$ & $18(1.5 \%)$ \\
\hline $\begin{array}{l}\text { Drug interac- } \\
\text { tions/Pregnan- } \\
\text { cy, } n(\%)\end{array}$ & $20(1.2 \%)$ & $7(1.2 \%)$ & $13(1.1 \%)$ \\
\hline $\begin{array}{l}\text { Drug interac- } \\
\text { tion }\end{array}$ & $13(0.8 \%)$ & $4(0.7 \%)$ & $9(0.8 \%)$ \\
\hline $\begin{array}{l}\text { Pregnancy/ } \\
\text { intended } \\
\text { pregnancy }\end{array}$ & $7(0.4 \%)$ & $3(0.6 \%)$ & $4(0.4 \%)$ \\
\hline $\begin{array}{l}\text { Simplification/ } \\
\text { Compliance, } \\
n(\%)\end{array}$ & $134(7.9 \%)$ & $61(10.8 \%)$ & $73(6.4 \%)$ \\
\hline $\begin{array}{l}\text { Treatment } \\
\text { simplification }\end{array}$ & $113(6.7 \%)$ & $57(10.1 \%)$ & $56(4.9 \%)$ \\
\hline $\begin{array}{l}\text { Non-compli- } \\
\text { ance }\end{array}$ & $21(1.2 \%)$ & $4(0.7 \%)$ & $17(1.5 \%)$ \\
\hline Other, $n(\%)$ & $120(7.1 \%)$ & $42(7.5 \%)$ & 78 (6.9\%) \\
\hline $\begin{array}{l}\text { Patients wish/ } \\
\text { decision }\end{array}$ & $42(2.5 \%)$ & $11(2.0 \%)$ & $31(2.7 \%)$ \\
\hline $\begin{array}{l}\text { Physicians } \\
\text { decision }\end{array}$ & $17(1.0 \%)$ & $6(1.1 \%)$ & $11(1.0 \%)$ \\
\hline Death & $17(1.0 \%)$ & $7(1.2 \%)$ & $10(0.9 \%)$ \\
\hline Other & $44(2.5 \%)$ & $18(3.2 \%)$ & $26(2.3 \%)$ \\
\hline Missing, $n(\%)$ & $53(3.1 \%)$ & $10(1.8 \%)$ & $43(3.8 \%)$ \\
\hline
\end{tabular}

Table 4. Laboratory parameters.

\begin{tabular}{lccc}
\hline & Mean at BL & $\begin{array}{c}\text { Mean change } \\
\text { from BL at 4 years } \\
\text { of follow-up }\end{array}$ & $\begin{array}{c}\text { Median fol- } \\
\text { low-up time } \\
\text { (months) }\end{array}$ \\
\hline $\begin{array}{c}\text { Creatinine (mg/ } \\
\text { dl) }\end{array}$ & 0.85 & -0.03 & 12.2 \\
eGFR (mL/min) & 80.97 & -7.01 & 12.2 \\
$\begin{array}{c}\text { Total cholesterol } \\
\text { (mg/dl) }\end{array}$ & 188.61 & 11.82 & 14.9 \\
$\begin{array}{c}\text { Serum HDL (mg/ } \\
\quad \text { dL) }\end{array}$ & 49.62 & 4.52 & 15.0 \\
$\begin{array}{c}\text { Serum LDL (mg/ } \\
\text { dL) }\end{array}$ & 111.38 & 2.71 & 14.9 \\
$\begin{array}{c}\text { Serum Triglycer- } \\
\text { ides (mg/dl) }\end{array}$ & 147.16 & 15.88 & 14.8 \\
\hline
\end{tabular}

trials with DRV/c illustrate how the characteristics of patient populations are shifting towards less advanced patients and higher rates of treatment success. In the AMBER trial [23] which evaluated DRV/c/TAF/FTC only $7.0 \%$ of the treatment naïve subjects had a baseline CD 4 cell count $\leq 200$ cells $/ \mathrm{mm}^{3}$ vs. $30.9 \%$ in this Belgium cohort. 91.4\% of the treatment naive subjects in AMBER had viral suppression after 48 weeks. In the EMERALD study [18] which evaluated switching to DRV/c/TAF/ FTC in virologically suppressed subjects the median baseline CD4 count was high $\left(628\right.$ cells $\left./ \mathrm{mm}^{3}\right) .94 .9 \%$ of the switched subjects maintained virological suppression suppressed after 48 weeks.

The rate of discontinuation of $\mathrm{DRV} / \mathrm{r} \mathrm{QD}$ in this analysis was low, and rarely due to lack of efficacy. Contrary to what would be expected the incidence of virological failure was numerically higher in the subjects on firstline ART ( $1.2 \%)$, than in the experienced subjects (0.5\%), possibly reflecting the nature of this real-world cohort study. No unexpected adverse events were reported and the good tolerability that was seen in previous clinical studies comparing DRV/r with LPV/r or the integrase inhibitors raltegravir and dolutegravir was confirmed $[4,6,24]$. This is in line with the Swedish InfCare study, where DRV/r was the most commonly used third agent for treatment-experienced patients and showed the lowest risk for treatment discontinuation [22].

A subgroup of patients received DRV/r monotherapy. The MONET [21], MONOI [25], PROTEA [20] and PIVOT [26] trials have shown that DRV/r monotherapy can be considered as a treatment option for patients with stable virological suppression on combination therapy (HIV-1 RNA < 50 copies/mL for at least six months). $\mathrm{DRV} / \mathrm{r}$ monotherapy has also recently been reported to exhibit a good efficacy and safety profile in routine clinical practice $[14,15,27]$. In this cohort, DRV/r QD monotherapy was well tolerated, adverse events were mainly GI related as observed in the MONET and PROTEA monotherapy trials $[20,28]$ as well as in another real world study from Spain [14].

A low CD4 nadir ( $<200$ cells $/ \mu$ l) has previously been shown to be predictive of treatment failure in PROTEA [29]. This, however, has neither been observed in our cohort nor in a recent observational study [14].

Our study has several limitations, mainly due to its observational retrospective design, leading to potential selection biases and limited medical history and follow-up details. Information on ART regimens received before switch to $\mathrm{DRV} / \mathrm{r}$, reasons for switching and details of ART-regimens after DRV discontinuation were not available, as details on comorbidities, polypharmacy. Pre-existing resistance associated mutations (RAMs) before commencing DRV-based ART or details on the occurrence of RAMs at treatment failure were not systematically captured at site level and are therefore not available in this retrospective real-world cohort analysis.

While the analysis is based on observations ending December 2014, the findings inform current treatment with boosted DRV, with the two new presentations containing cobicistat-boosted darunavir (DRV/c and $\mathrm{DRV} / \mathrm{c} / \mathrm{TAF} / \mathrm{FTC}$ ) which have the potential to increase the convenience of DRV-based ART. 


\section{Conclusion}

This retrospective cohort analysis of patients on DRV/r QD in Belgium confirms the long-term efficacy and good tolerability of DRV/r QD in a real-life setting. The rate of discontinuation of DRV/r QD in daily practice was low, and rarely due to lack of efficacy. No unexpected adverse events were reported.

\section{Acknowledgements}

The authors thank the participating centres, Business \& Decision for the data collection and T.O.M. Life Science Consulting for medical writing services. Furthermore, the authors thank Suzy Van Sanden and Gert Loriers from Janssen for their contribution. The study was funded by Janssen-Cilag NV, Belgium. These data were presented at the HIV Drug Therapy congress 2016 in Glasgow (Posters \#131 and \#137) and during the national BREACH congress in Belgium (Nov 2016).

\section{Disclosure statement}

The authors declared the following potential conflicts of interest with respect to the research, authorship and/or publication of this article: SW reports grants from Janssen, during the conduct of the study; grants from BMS, Gilead, Janssen, ViiV and MSD, outside the submitted work; RD has nothing to disclose; EF reports grants from Janssen, BMS, Gilead and ViiV, during the conduct of the study; JCG reports grants from Janssen, ViiV healthcare, and Gilead, outside the submitted work; MM and LV report grants from Janssen, during the conduct of the study; EvW reports grants from Janssen, during the conduct of the study. PT and HP are employees of Janssen-Cilag Belgium.

\section{Funding}

This study was funded by Janssen-Cilag NV, Belgium. The corresponding author had full access to all the data in the study and was responsible for the final decision to submit for publication.

\section{References}

[1] Janssen-Cilag: Prezista (Darunavir). Summary of Product Characteristics [Internet]. [last updated May 11, 2016; cited 2016 Dec 14]. Available from: http:// www.ema.europa.eu/docs/en_GB/document_library/ EPAR_-_Product_Information/human/000707/ WC500041756.pdf

[2] EACS Guidelines Version 9.0 [Internet]. [cited 2017 Nov 6]. Available from: http://www.eacsociety.org/ guidelines/eacs-guidelines/eacs-guidelines.html

[3] DHHS Panel on Antiretroviral Guidelines for Adults and Adolescents. Guidelines for the Use of Antiretroviral Agents in HIV-1 Infected Adults and Adolescents Oct 2017 [Internet]. 2017 [cited 2017 Oct 25]. Available from: https://aidsinfo.nih.gov/ contentfiles/lvguidelines/adultandadolescentgl.pdf

[4] Orkin C, DeJesus E, Khanlou H, et al. Final 192-week efficacy and safety of once-daily darunavir/ritonavir compared with lopinavir/ritonavir in HIV-1-infected treatment-naive patients in the ARTEMIS trial. HIV Med. 2013 Jan;14(1):49-59.
[5] Molina J-M, Clotet B, van Lunzen J, et al. Oncedaily dolutegravir versus darunavir plus ritonavir for treatment-naive adults with HIV-1 infection (FLAMINGO): 96 week results from a randomised, open-label, phase 3b study. Lancet HIV. 2015 Apr;2(4):e127-e136.

[6] Lennox JL, Landovitz RJ, Ribaudo HJ, et al. Efficacy and tolerability of 3 nonnucleoside reverse transcriptase inhibitor-sparing antiretroviral regimens for treatmentnaive volunteers infected With HIV-1: a randomized, controlled equivalence trial. Ann Intern Med. 2014 Oct 7;161(7):461-471.

[7] Cahn P, Fourie J, Grinsztejn B, et al. Week 48 analysis of once-daily vs. twice-daily darunavir/ritonavir in treatment-experienced HIV-1-infected patients. AIDS. 2011 Apr;25(7):929-939.

[8] Lathouwers E, Wong EY, Luo D, et al. Low HIV1 resistance in subjects using darunavir once-daily regimens across studies. Poster 505 CROI 2017 Seattle [Internet]. 2017 [cited 2017 Apr 4]. Available from: http://www.croiconference.org/sites/default/files/ posters-2017/505_Lathouwers.pdf

[9] El Bouzidi K, White E, Mbisa JL, et al. HIV-1 drug resistance mutations emerging on darunavir therapy in PI-naive and -experienced patients in the UK. J Antimicrob Chemother. 2016 Dec;71(12):3487-3494.

[10] Antinori A, Meraviglia P, Monforte A d'Arminio, et al. Effectiveness, durability, and safety of darunavir/ ritonavir in HIV-1-infected patients in routine clinical practice in Italy: a postauthorization noninterventional study. Drug Des Devel Ther. 2016;10:1589-1603.

[11] Lackey P, Mills A, Carpio F, et al. Virologic effectiveness of abacavir/lamivudine with darunavir/ritonavir versus other protease inhibitors in treatment-experienced HIV-infected patients in clinical practice. Clin Drug Investig. 2017 Jan;37(1):51-60.

[12] Podzamczer D, Imaz A, Perez I, et al. Abacavir/ lamivudine plus darunavir/ritonavir in routine clinical practice: a multicentre experience in antiretroviral therapy-naive and -experienced patients. J Antimicrob Chemother. 2014 Sep;69(9):2536-2540.

[13] Menzaghi B, Ricci E, Carenzi L, et al. Safety and durability in a cohort of HIV-1 positive patients treated with once and twice daily darunavir-based therapy (SCOLTA Project). Biomed Pharmacother. 2013 May;67(4):293-298.

[14] Santos JR, Moltó J, Llibre JM, et al. Antiretroviral simplification with darunavir/ritonavir monotherapy in routine clinical practice: safety, effectiveness, and impact on lipid profile. PLoS ONE. 2012;7(5):e37442.

[15] Pasquau J, López-Cortés L, Isabel Mayorga MI, et al. Monotherapy with darunavir/ritonavir is effective and safe in clinical practice. J Int AIDS Soc. 2014;17(4 Suppl 3):19813.

[16] European Medicines Agency Rezolsta [Internet]. [cited 2017 Nov 9]. Available from: http://www.ema. europa.eu/ema/index.jsp?curl=pages/medicines/ human/medicines/002819/human_med_001817. jsp\&mid=WC0b01ac058001d124

[17] European Medicines Agency Symtuza [Internet]. [cited 2017 Nov 9]. Available from: http://www.ema. europa.eu/ema/index.jsp?curl=pages/medicines/ human/medicines/004391/human_med_002165. jsp\&mid=WC0b01ac058001d124

[18] Orkin C, Molina J-M, Negredo E, et al. Efficacy and safety of switching from boosted protease inhibitors plus emtricitabine and tenofovir disoproxil fumarate 
regimens to single-tablet darunavir, cobicistat, emtricitabine, and tenofovir alafenamide at 48 weeks in adults with virologically suppressed HIV-1 (EMERALD): a phase 3, randomised, non-inferiority trial. Lancet HIV. 2018 Jan;5(1):e23-e34.

[19] Brandt RS, Frederiksen CM. Data collection on adverse events of anti-HIV drugs - the D:A:D STUDY [Internet]. [cited 2016 Dec 16]. Available from: http:// www.cphiv.dk/Portals/0/files/Study\%20documents/ DAD_15th_merger_SOP_v2_April_2014.pdf

[20] Girard PM, Antinori A, Arribas JR, et al. Week 96 efficacy and safety of darunavir/ritonavir monotherapy vs. darunavir/ritonavir with two nucleoside reverse transcriptase inhibitors in the PROTEA trial. HIV Med. 2017 Jan;18(1):5-12.

[21] Arribas JR, Clumeck N, Nelson M, et al. The MONET trial: week 144 analysis of the efficacy of darunavir/ ritonavir (DRV/r) monotherapy versus DRV/r plus two nucleoside reverse transcriptase inhibitors, for patients with viral load $<50$ HIV-1 RNA copies/mL at baseline. HIV Med. 2012 Aug;13(7):398-405.

[22] Häggblom A, Lindbäck S, Gisslén M, et al. HIV drug therapy duration; a Swedish real world nationwide cohort study on InfCareHIV 2009-2014. PLOS ONE. 2017;12(2):e0171227.

[23] Gallant J, Eron J, Orkin C, et al. Week 48 results of AMBER: A Phase 3, randomised, double-blind trial in antiretroviral treatment (ART)-naïve HIV-1-infected adults to evaluate the efficacy and safety of the oncedaily, single-tablet regimen (STR) of darunavir/ cobicistat/emtricitabine/tenofovir alafenamide (D/C/F/ $\mathrm{TAF})$ versus darunavir/cobicistat (DRV/c) plus emtricitabine/tenofovir disoproxil fumarate (FTC/ TDF). 16th European AIDS Conference; Milan; 2017, PS8/2

[24] Molina J-M, Clotet B, van Lunzen J, et al. Once-daily dolutegravir is superior to once-daily darunavir/ ritonavir in treatment-naïve HIV-1-positive individuals: 96 week results from FLAMINGO. J Int AIDS Soc. 2014 Nov 2;17(4(Suppl 3)) [Internet]. [cited 2014 Nov 5]. Available from: http://www.jiasociety.org/index.php/ jias/article/view/19490

[25] Valantin MA, Lambert-Niclot S, Flandre P, et al. Longterm efficacy of darunavir/ritonavir monotherapy in patients with HIV-1 viral suppression: week 96 results from the MONOI ANRS 136 study. J Antimicrob Chemother. 2012 Mar;67(3):691-695.

[26] Paton NI, Stöhr W, Arenas-Pinto A, et al. Protease inhibitor monotherapy for long-term management of HIV infection: a randomised, controlled, open-label, non-inferiority trial. Lancet HIV. 2015 Oct;2(10):e417e426.

[27] El Bouzidi K, Collier D, Nastouli E, et al. Virological efficacy of PI monotherapy for HIV-1 in clinical practice. J Antimicrob Chemother. 2016 Nov;71(11):3228-3234.

[28] Arribas JR, Horban A, Gerstoft J, et al. The MONET trial: darunavir/ritonavir with or without nucleoside analogues, for patients with HIV RNA below 50 copies/ ml. AIDS Lond Engl. 2010 Jan 16;24(2):223-230.

[29] Antinori A, Clarke A, Svedhem-Johansson V, et al. Week 48 efficacy and central nervous system analysis of darunavir/ritonavir monotherapy versus darunavir/ ritonavir with two nucleoside analogues. AIDS Lond Engl. 2015 Sep 10;29(14):1811-1820. 